TEME, г. XLI, бр. 4, октобар - децембар 2017, стр. 1093-1111

Претходно саопштење

DOI: 10.22190/TEME1704093B

Примљено: 1. 8. 2016

UDK $81 ' 27=131.1(497.5)$

Ревидирана верзија: 1. 6. 2017.

Одобрено за штампу: 15. 11. 2017.

\title{
СОЦИОЛИНГВИСТИЧКИ ПОГЛЕД НА САВРЕМЕНИ ЈЕЗИК ИТАЛИЈАНА У ИСТРИ И РИЈЕЦИ
}

\author{
Александра Блатешић , Кристијан Екер \\ Универзитет у Новом Саду, Филозофски факултет, Нови Сад, Србија \\ *ablatesic@yahoo.it
}

\begin{abstract}
Апстракт
У овом раду бавићемо се анализом језика којим говоре Италијани у Истри, а пошто то није само стандардни италијански језик, у предмет нашег истраживања улазе још хрватски језик и истарски дијалекат (тзв. istro-veneto). Посматраћемо развој језика Италијана у периоду од друге половине 20. века до савременог доба, јер је то било време највећих промена. Наиме, након Другог светског рата код Италијана у Истри јавио се комплекс мањине, јер су сматрали да њихов језик нема никакву друштвену улогу, а до шездесетих година прошлог века билингвизам је био посматран искључиво у негативном светлу, што је додатно утицало на начин коришћења италијанског као матерњег језика у нематичним државама, које су у овом случају Хрватска и Словенија. Поред општег социолингвистичког приказа положаја Италијана у Истри и Ријеци, у овом раду ћемо разматрати језик и менталитет овог народа у романима Нелиде Милани, која је успела да веома верно и темељно опише њихов друштвени положај и психолошко стање у различитим социолошким улогама и контекстима.
\end{abstract}

Кључне речи: италијански језик, плурилингвизам, социопсихолингвистика, Нелида Милани, Истра.

\section{SOCIOLINGUISTIC VIEW ON CONTEMPORARY LANGUAGE OF ITALIANS IN ISTRIA AND RIJEKA}

\begin{abstract}
In this article we will deal with the analysis of the language spoken by the Italians in Istria, and since it is not just the standard Italian language, the subject of our research included more Croatian and Istrian dialect (called istro-veneto). We will observe the development of Italian language in the period from the second half of the 20th century to modern times, because it was the time of the biggest change. After the Second World War when the Italians in Istria reported to a complex minority, because they thought that their language had no social role, and bilingualism was viewed in purely negative terms by the $60 \mathrm{~s}$ of last century, which further affected the manner of use Italian as a mother tongue in non-core countries, in this case in Croatia and Slovenia. In addition to the general sociolinguistic display position of Italians in Istria
\end{abstract}


and Rijeka in this paper we consider the language and the mentality of the people in novels of Nelida Milani, who was able to describe very accurately and thoroughly their social position and psychological state in different roles and sociological contexts.

Key words: Italian, plurilingualism, sociopsycholinguistics, Nelida Milani, Istria.

\section{УВОД}

Веома сложена социолингвистичка ситуација у Истри условљена је разноврсношћу нација које заједно живе и раде на овом простору, на којем су често упућени једни на друге упркос језичким, националним и културолошким разликама. Поред Словенаца и Хрвата као већинског становништва, у Истри живи одређени број Италијана који покушава да се прилагоди другој земљи, али и да остане у контакту са својом матичном државом. Након краћег историјског приказа о дешавањима после Другог светског рата, који је веома важан период за разумевање сложености социополитичког положаја Италијана у Истри, бавићемо се анализом језика као прве баријере са којом су се суочили досељеници из ове државе. Италијани су се на овом простору нашли у веома специфичној ситуацији у којој су се за међусобну комуникацију служили посебно развијеним дијалектом, тзв. истарско-венетским, док су стандардним италијанским говорили у изразито формалним ситуацијама. Стога ћемо приказати најтипичније интерференције и промене језичког кода, које су уобичајене у свакодневној комуникацији и које најчешће не доводе до ремећења комуникацијског кода. Скренућемо пажњу и на исказе који имају збуњујући ефекат на једнојезичне говорнике италијанског, са којима се истарски Италијани сусрећу приликом боравка у Италији.

Пошто Истра и Кварнерска острва обилују разним језичким идиомима $^{1}$ (Lalli Paćelat, Štokovac 2011, str. 82-83), ограничили смо наше истраживање на стандардни италијански, истарско-венетски и хрватски, као најзаступљеније идиоме у истраживаној регији (Ријека и Пула). Као извор информација за језичку и социопсихолошку анализу истарских Италијана користили смо књижевна и стручна дела истарске књижевнице Нелиде Милани, која је веома упечатљиво успела да опише унутрашњу драму кроз коју још увек пролазе чак и нове генерације Италијана.

\footnotetext{
${ }^{1}$ У овој регији су, поред хрватског и словеначког, присутни стандардни италијански, истро-венетски дијалекат, кајкавски, чакавски, истарски дијалекат, истарско-румунски и остали језички идиоми, уз пратеће културолошке и социолингвистичке разлике.
} 


\section{ПРИКАЗ ДРУШТВЕНОГ ПОЛОЖАЈА ИТАЛИЈАНА НАКОН ДРУГОГ СВЕТСКОГ РАТА}

Данас у Истри живи око 30.000 Италијана, с тим да је огромна већина њих (27.000) настањена у Хрватској, док се преостали живаљ (3000) налази у танком приобаљу полуострва које припада Словенији. Само поређења ради, напомињемо да је до 1946. године, односно до Париског уговора, којим је потврђено да Истра прелази под југословенску власт, на том подручју живело око 500.000 Италијана (Rumici, 2001, стр. 26). Највећи део истарских Италијана (око 250.000²) напустио је своје домове непосредно након рата, док су они који су остали годинама живели у некој врсти изолације, нарочито после 1948. Наиме, тада је председник бивше СФРЈ Јосип Броз Тито прекинуо сарадњу са лидером Совјетског Савеза Јосифом Стаљином, па су југословенске власти почеле да сматрају сумњивим све остале народе који су живели на подручју Југославије, а посебно Италијане, које су уопштено сматрали фашистима. Иако никада није био јасно наведен разлог због којег су неки међу њима завршили на Голом отоку, а неки у затвору, такве одлуке биле су снажно политички обојене (Scotti, 1991). Упркос свим тешкоћама, Италијани су се борили прво за опстанак својих школа и новина, а касније радија и телевизије, при чему су истицали значај борбе за свој сопствени језик, који већина људи сматра „важним делом националног идентитета и необично моћним симболом друштвене солидарности" (Сапир, 1984, стр. 61).

Најјаче средство којим су се истарски Италијани служили за очување и неговање језика била је књижевност, јер су многи међу њима били писци, а објављивали су како романе тако и збирке поезије. Стога је књижевност за њих постала „топос”, тј. место на којем су се сусретали са истарским Словенима и место које је касније омогућило разумевање разлога због којих су припадници тих двају народа показивали међусобну нетрпељивост.

\footnotetext{
${ }^{2}$ Број Италијана који је напустио Истру још увек је споран: Италијанске власти тврде да је око 300.000 људи напустило своје домове од 1946. до 1950, у периоду који су италијански историчари назвали „исељење” (Rumici, 2001, стр. 45). Ипак, тај податак није тачан зато што су многи Италијани напустили Истру после 1950. године због економских, а не политичких разлога. Укупно 300.000 Италијана напустило је све бивше италијанске територије у Истри и Далмацији, а многи међу њима (још увек се не зна тачан број) једноставно су се вратили кући пошто и нису били пореклом из Истре или Далмације, већ су радили у државној администрацији Краљевине Италије, тако да се не могу сматрати избеглицама. Клаудио Угуси тврди да је одмах након потписивања Париског уговора Истру и Ријеку напустило између 200.000 и 250.000 Италијана, али не више (Ugussi, 2002, стр. 1-2).
} 
Књижевност је тако постала битна за очување језика италијанског компонента ${ }^{3}$, те је постала моћно средство помоћу којег су Италијани успели да новим генерацијама пренесу матерњи језик. Веома је занимљиво посматрати однос који данас имају млади Италијани према свом језику и сагледати како се временом мењао истарски лингвистички контекст. Наиме, нове генерације истарских Италијана су двојезичне, а понекад чак и тројезичне. У кућном окружењу причају дијалектом, који се назива истарско-венетски (dialetto istro-veneto), а у школи говоре и пишу стандардним италијанским језиком. У комуникацији са пријатељима, тј. у неформалном контексту, најчешће се служе хрватским, у мањем делу полуострва словеначким језиком, а понекада и чакавским наречјем. Занимљива је различита функција коју имају ови језици и дијалекти у различитим социолошким контекстима. Тако истарско-венетски дијалекат има искључиво комуникативну функцију у породичном миљеу Италијана, док чакавски поприма шаљиву конотацију. Наиме, Италијани и Хрвати заузимају исти став према чакавском дијалекту, са којим се не идентификују према националној основи, већ га сматрају „сељачким” језиком, односно језиком обичног плебса, а не неког одређеног народа.

Лингвиста који жели да се бави овим изразито сложеним социолингвистичким положајем италијанског компонента у Истри требало би да у своја истраживања укључи историјске и психолошке утицаје. Стога није случајност што је највећи истраживач ове теме управо Нелида Милани, која се бавила психосоциолингвистиком на Универзитету у Пули. Нелида Милани је током шездесетих и седамдесетих година прошлог века била посвећена само стручно-научним истраживањима и није се бавила књижевношћу све док се односи између италијанске и југословенске власти нису побољшали ${ }^{4}$. Ова ауторка је касније постала једна од најпознатијих и најзначајнијих италијанских списатељица, а њени романи су се показали веома ко-

\footnotetext{
${ }^{3}$ У овом раду користићемо термин компонент уместо речи мағина, која имплицира да је неко „мањи” од неког другог, односно семантизује негативно вредновање значаја одређене друштвене заједнице. Сваки ентитет мора имати своје место у друштву, те са овакве тачке гледишта „мањине” не постоје.

${ }^{4}$ Италијанима су се више супротстављале хрватске него југословенске власти. Хрвати су добро упамтили италијанску фашистичку доминацију, која је трајала од 1918. до 1945. године и која је била нељудска и немилосрдна према свим неиталијанским народима у Истри. Иако је италијански фашиста Мусолини словенски народ сматрао „нижом расом”, Италијани у Истри имали су другачије схватање, које су темељно описали у својим делима да би на крају тражили помирење са Југословенима, поготово са Хрватима и Словенцима. Италијанске власти су, са друге стране, испричале само други део те историје (масовна убиства Италијана у фојбама, освета Хрвата Италијанима итд.) прикривајући тиме сопствену одговорност за почињена дела.
} 
рисним за разумевање психолошке и социолингвистичке структуре Италијана у Истри.

\section{УТИЦАЈ БИЛИНГВИЗМА НА РАЗВОЈ ЈЕЗИКА ИСТАРСКИХ ИТАЛИЈАНА}

Билингвизам као појава не тиче се само лингвистике већ има и егзистенцијални карактер, што је нарочито истакнуто у документима Европске уније и Европског савета, у којима се предлаже примена политике језичке заштите и промоције свих, па и мање заступљених језика (British Council, 2012, стр. 13). Савет Европе од свог оснивања 1949. године промовише људска права и демократију као вредности које чине основу њене језичке политике (British Council 2012, стр. 15) и које се остварују путем разних конвенција, докумената и препорука. Посебно место заузима заштита минорних и регионалних језика, дијалеката и слабо распрострањених националних језика због смањеног броја говорника.

Младе генерације у Истри настале су и одрасле у двојезичном окружењу. Деца у таквим условима усвајају језик кроз три фазе: прва траје до друге године и у њој дете меша језике и не може да разликује која реч припада ком језику. У другој фази дете почиње да разликује језике, али још увек меша структуре и речи двају језика. У трећој фази дете потпуно разликује језике и меша их само када се налази у кругу људи који су двојезични као и оно (Milani, 2003, стр. 85). Понекад се дешава да говорник меша језике и када се налази у једнојезичном контексту, али се та појава запажа углавном код необразованих људи или у ситуацијама када се говорник жаргонски користи језиком, па не мора да се контролише као у формалном обраћању (нпр. у разговору са професорима у школи и сл.).

Често је присутан феномен назван code-switching ${ }^{5}$, приликом којег се мешају италијански, хрватски и истарско-венетски дијалекат, што можемо видети у примерима ${ }^{6}$ наведеним даље у тексту (17). У описаним случајевима лексичке и граматичке границе се отварају, а италијански, истарско-венетски дијалекат и хрватски постају један језик. Ова појава је нарочито истакнута у делима Нелиде Милани, чији дијалози обилују примерима наизменичне употребе и ин-

\footnotetext{
${ }^{5}$ Ова лингвистичка појава односи се на пребацивање кода, при чему говорник меша два или више језика, дијалекта или језичка варијетета у оквиру једног дискурса. Карактеристична је за Италијане у Италији због мешања стандардног италијанског и дијалекта, али и за италијанске имигранте (Bertini Malgarini 1994).

${ }^{6}$ Прва два примера забележена су током теренског рада и личног разговора К. Екера са младим Италијанима у Пули (Екер 2011), док су остали ексцерпирани из дела Нелиде Милани (Milani, 2003).
} 
терференције ових језика. Наведени искази већином почињу речима истарско-венетског дијалекта или италијанског стандарда, али се у другом делу реченице јављају хрватске речи, и то у положају објекта (1-3), главне реченице (4), именског предиката (5) и придева (7). Само један исказ почиње хрватском речју, и то прилогом у примеру (6).

(1) „Go le traperice $*^{7}$ nove!“

(срп. Имам нове фармерице / тексас панталоне.)

Уметнута хрватска лексема traperice односи се на тексас панталоне, док би целокупан исказ на стандардном италијанском био Но i pantaloni jeans nuovi. У структури са хрватском лексемом Go le traperice* nove дошло је до слагања италијанског придева $n(u)$ ovo са хрватском именицом traperice у множини женског рода, која је добила и адекватни италијански одређени члан $l e$, иако хрватски језик нема категорију члана. До овакве замене језичког кода дошло је захваљујући једној заједничкој особини оба језика. Наиме, и у хрватском и у италијанском постоје именице и придеви женског рода са завршетком на - $a$ у једнини и на -е у множини (нпр. леп $a$ жен $a /$ лепе жене: donna bella / donne belle), што је олакшало наизменичну употребу оба језика.

(2) „Dammi le slušalice* che voglio ascoltar el nuovo album de Baglioni!"

(срп. Дај ми слушалице, хоћу да слушам нови Баљонијев албум.)

У овај исказ унета је хрватска лексема slušalice уместо италијанске cuffie, са одређеним чланом за именице женског рода у множини $l e$, као у претходном примеру. У реченици је искоришћен и колоквијални облик che каузативног значења уместо perché, као и одређени члан за именице мушког рода у једнини $e l$ на истарско-венетском дијалекту, уместо стандардног $i l$. Ова реченица би у стандардном италијанском језику имала следећи облик: Dammi le cuffie, perché voglio ascoltare il nuovo album di Baglioni.

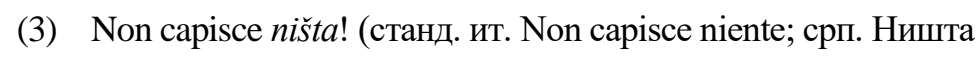
не разуме.)

У овој реченици уместо италијанске неодређене заменице за негацију niente употребљена је хрватска заменица ništa, у објекатском положају. У хрватском је могућ иницијални и финални положај ове заменице у реченици са употребљеном речцом за негацију пе ( $\mathrm{Ne}$

\footnotetext{
${ }^{7}$ Астериском смо обележили неправилне италијанске облике под утицајем доминантног хрватског језика, као и хрватске речи у италијанским исказима.
} 
razume ništa / Ništa ne razume), док италијански омогућава две варијанте: једну са речцом за негацију на почетку исказа и неодређеном заменицом у финалном положају (Non capisce niente) и другу са иницијалном неодређеном заменицом за негацију без додавања речце non за негацију (Niente capisce). Овде је дошло до промене кода управо у структури која је идентична у оба језика, тј. оној са дуплом негацијом и финалним положајем неодређене заменице.

(4) Se ha sete mora piti! (станд. ит. Se ha sete deve bere, срп. Ако је жедан, мора пити.)

У италијанској кондиционалној реченици дошло је до промене језика у делу независне реченице, која је изречена на хрватском тоra piti уместо ит. deve bere. Структура ове реченице је иначе идентична у оба језика, што олакшава промену језичког кода.

(5) Ma questa è proprio una lijepa macchina! (станд. ит. Ma questa è proprio una bella macchina; срп. Али ово је баш један леп аутомобил.)

У овој реченици дошло је до промене језика у финалном делу приликом употребе придева lijepa на хрватском, док је редослед речи у потпуности исти. У целовитом италијанском исказу био би употребљен придев bella, такође у преноминалном положају, који углавном није типичан за италијанску именичку синтагму 8 . Ипак, исти ред речи се у овом исказу поклопио са хрватском структуром, те је дошло до лаке и спонтане замене кодова.

(6) Baš sam arrabbiata. (станд. ит. Sono proprio arrabbiata; срп. Баш сам љута.)

Ово је једини пример исказа који почиње на хрватском, вероватно због разлике у редоследу речи између италијанске и хрватске реченице. У инципиту италијанске реченице налази се глагол essere (бити), што није могуће у хрватском исказу (sam baš arrabbiata*). Притом, хрватски прилог baš у иницијалном положају има маркирано значење, док се у италијанском тај ефекат постиже интонацијом, а не другачијим позиционирањем прилога proprio. Без обзира на ову разлику између два језика, придев у једнини женског рода arrabbiatalljuta у реченицама оба језика заузима исто место, те се промена језичког кода реализује само у иницијалном делу реченице инверзијом речи.

\footnotetext{
${ }^{8}$ У италијанском језику је уобичајена постпозитивна употреба придева, док промену положаја могу остварити само поједини придеви који добијају друго или фигуративно значење, нпр. пиоvо (други/нов), diverso (различит/прилично) alto (висок/важан), povero (сиромаман/јадан) итд.
} 
(7) La xe assai uslužna (станд. ит. Lei è molto diligente; срп. Она је веома вредна.) (Milani, 2003, стр. 131)

У овој једноставној исказној реченици употребљен је истарско-венетски дијалекат уз употребу хрватског придева у једнини женског рода у финалном положају uslužna уместо италијанског облика diligente. Ред речи у реченици је иначе исти у оба језика.

Људи рођени у регијама попут Истре, где се језици и културе мешају, имају сигурно веће могућности да се успешно суоче са различитим културама него људи који су се родили у једнојезичном контексту. Предност је што данас више нико не сматра билингвизам недостатком као што се то често дешавало у прошлости. У свом дијахроном приказу билингвизма Бејкер наводи да су научници од 1920. до 1960. године сматрали да билингвизам има негативне последице на развој мисли и уопште на психолошки развој (Baker, 1996, стр. 118). Тек 1962. године појављује се прва документована студија о позитивним ефектима билингвизма, који суштински доприноси когнитивном развоју (Peal, Lambert, 1962). У бројним савременим научним студијама и документима (Fabbro 1996, Bialystock 2001, Daloiso 2009, Заједнички европски оквир за живе језике 2003, Hnízdo 2008) билингвизам је препознат као пожељна појава, а с обзиром на језичку разноврсност старог континента, билингвизам све чешће прелази у плурилингвизам, који се развија као друштвени феномен, не због способности служења бар двома језицима, већ због тенденције ка стварању вишеструких кодова комуникације (Luise, 2013, стр. 527).

\section{КОМПЛЕКС МАЬИНЕ КОД ИСТАРСКИХ ИТАЛИЈАНА}

Ипак билингвизам, као и плурилингвизам, прате одређени социолошки, па и психолошки проблеми у тренутку сусретања са другим људима из непознате средине. Тако Хниздо наводи Истру као пример мале језичке заједнице у којој има много билингвалних говорника (Hnízdo 2008, стр. 9-10), али којима познавање више језика нимало не доприноси развоју осећаја европског идентитета. Штавише, управо у тим микро регијама у којима се говори више језика, билингвалност и плурилингвалност намећу се као препрека у стварању општег европског идентитета (Hnízdo 2008, стр. 14). Ова појава је поготово изражена када млади Италијани путују ван Истре, тј. када се морају суочавати са људима који не припадају њиховом двојезичном и тројезичном свету, те не могу да користе ни хрватске ни дијалекатске речи. Несвесно користе позајмљенице, што их може довести у непријатне ситуације. Италијани у Истри сами себе сматрају мањином, првенствено због тога што не владају у потпуности својим језиком. 
Ради илустровања наведеног, навешћемо неколико примера исказа истарских студената који похађају италијанске универзитете, али који услед непотпуног владања стандардом праве структуре у којима се огледа тзв. code-mixing. Овај феномен се, за разлику од претходно описаног (code-switching), одиграва најчешће на несвесном нивоу, када долази до мешања језичких кодова унутар структуpa, при чему могу настати нови и углавном неправилни језички облици (Kendall 2006, стр. 205-224).

(8) Molti giovani nell'età della guerra* уместо Molti giovani durante la guerra, jep је облик nell'età della guerra* настао као позајмљеница из хрватског 'у време рата' (Milani, 2003, стр. 139).

За италијански временски прилог durante речници италијанског језика (нпр. Клајн 1997, Deanović, Jernej 2002) дају превод „током / за време", међутим, у преласку са хрватског на италијански језик не могу да се искористе сви понуђени облици у дословном преводу. Правилно коришћење италијанског прилога durante („,током / за време”) и структуре nell'età di (,у време / у доба") захтева темељно познавање језичког контекста, као и уобичајених спојева лексема и колокација, а оно се стиче континуираном употребом стандардног и књижевног италијанског језика. Италијани у Истри у свакодневној комуникацији не морају да се служе искључиво једним кодом, јер се међусобно одлично разумеју и када мешају идиоме којима се користе. Та навика им, међутим, отежава комуникацију са говорницима из једнојезичних средина који више пажње посвећују стилској диференцијацији. Поред тога, у хрватском језику могуће је рећи tokom rata и za vreme rata, док је у италијанском стандарду уобичајена само ова прва структура, тј. durante la guerra.

(9) Oggi la professoressa mi ha alzato*. (срп. Данас ме је професорииа испитала)

Облик mi ha alzato у овом исказу је преводна позајмљеница хрватске структуре Digla me je, која је неправилно употребљена, јер би исказ у стандардном италијанском садржао потпуно други глагол interrogare (испитатu): Oggi la professoressa mi ha interrogato (Milani, 2003, стр. 97).

(10) La nave è affondata nel passato secolo*.

(срп. Брод је потопљен у прошлом веку)

Овај исказ садржи типичну хрватску структуру и prošlom veku уместо структуре стандардног италијанског nel secolo passato, у којој се придев налази у уобичајеном постноминалном положају (Milani, 2003, стр. 139). 
Занимљиво је да су исти феномен замене положаја придева регистровали Бошњаковић и Радовановић на примеру говора Срба у Румунији (Бошњаковић, Радовановић 2009, стр. 162) док су истраживали утицај румунског језика на синтаксу српског. Осећај „мањине” и комплекс ниже вредности постоје код сваког народа који живи у другој земљи и који не зна да ли припада земљи порекла или народу „већине”. Наведени аутори описују сличне социолингвистичке ситуације, истичући како контакт с аутохтоним становништвом усложњава етничке и лингвистичке прилике, јер долази до међусобних утицаја и прожимања у свим доменима материјалне и духовне културе (Бошњаковић, Радан 2010, стр. 135-136). Када сами говорници, као и њихов језик, изгубе престиж у економском, социјалном и историјском погледу, интерференција језика земље у којој се борави постаје још интензивнија, што је у Румунији последично довело до романизације српског становништва, тј. губљења матерњег језика, етапе иза које је уследила следећа у облику денационализације (Бошњаковић, Радан 2010, стр. 137).

Многи други народи који живе и раде ван отаџбине пролазе кроз различите фазе прилагођавања језику средине, као нпр. Мађари у Војводини (Звекић-Душановић 1999), Македонци у Србији (Станковић 2004) или Албанци у Србији (Трајковић 2013), али не улазе у процес денационализације. Италијане из Истре, младе и старе, прати снажан осећај усамљености, као и стид који се јавља услед осећаја неприпадности, али су на то утицали и бројни историјски разлози.

Наиме, раније су се Италијани осећали усамљено зато што никада нису имали праву подршку италијанске владе и италијанских интелектуалаца (Forza 2010, стр. 1): деценијама су италијанске власти сматрале истарске Италијане комунистима зато што нису желели да напусте своје домове; с друге стране, Југословени су још увек мислили да су Италијани фашисти. У таквом контексту, бити Италијан у Истри увек је значило бити непријатељ. Многи Италијани, нарочито током педесетих и шездесетих година прошлог века, одрекли су се свог идентитета: многи су уписали своју децу у југословенске школе јер су се бојали да не изгубе посао или да њихова деца једног дана неће моћи да се запосле ако буду завршила италијанске школе.

У једној Миланијевој приповеци La partita (Утакмица) главни јунак, средњошколац, уписује хрватску школу, али убрзо одлучује да се пресели у италијанску гимназију, из следећих разлога:

Раније је све било непрестано превођење са хрватског, мане-више сувопаран превод. Јесте ли икада помислили да је превођење глума? У глуми је један субјекат, а два су израза. И у првом и у другом случају долази до раздвајања. Када причам хрватски, то је један субјекат; али истовремено ја остајем ја, а то је други субјекат. Глума је производ прецииних мен- 
талних процеса, дакле није нужно ограничити је само на позорнииу. Превођење је глума и чини да се стално осећаш као на позорници, као да си удвостручен. (Milani, 1988, стр. 94, прев. Екер, Блатешић)

Превођење је деоба која подрива темеље идентитета човека који прича и који се осећа као на позорници: док он преводи са једног језика на други, концентрише се више на ознаку него на означено према Де Сосировој терминологији, а у том процесу губи везу међу њима, самим тим и језички знак. Језик, који спаја ознаку и означено у знак, постаје лаж, неистинита ствар, чиста структурална игра и није више средство за успостављање комуникације. То је права језичка трагедија, па тако и јунак романа Нелиде Милани, који жели да буде писац, чим се упише у италијанску школу, схвата да не зна довољно добро - италијански. Њему преостаје само да учи свој матерњи језик читајући што више:

Мени се много свиђа италијански. Али колико је тешко надокнађивати! Код куће говоримо на нашем дијалекту, а прави италијански никад нисам причао. Само ја знам патьу првог времена проведеног у италијанској иколи, када сам месецима живео у тишини пре него што сам почео да одмотавам клупко речи. Једино су ми рекламе надолазиле аутоматски...

Бацио сам се на читање као луд, и дању и ноћу... Свака кьига за мене била је не препрека коју сам морао да заобиђем, већ кључ који ми је омогућавао улазак у један нови свет, који ми је већ играо пред очима у једном од својих најчаробнијих видова. Пажљиво бих пратио причу, али ме је изнад свега фасичнирао стил. На магичном пољу стила престајемо да робујемо коначности и осећамо се слободно. (Milani, 1988, стр. 95, прев. Екер, Блатешић)

Овај млади ученик жели да добро научи свој језик јер разуме да само стил и форма гарантују исказивање суштине приче и говора. Стварност је језик; људско биће даје форму свету захваљујући свом језичком искуству: даје имена стварима истовремено их структуришући, док синтаксом уноси хијерахију међу њих. Дечак полако учи италијански по теорији Де Сосира, по којој једна реч добија своје значење на основу других речи које јој следе и претходе у реченици (Saussure, 1970).

Напор јунака, међутим, није довољан да би победио и „ћутање”, тај друштвени феномен по коме су у бившој Југославији мањине биле слободне да ћуте на језику на којем су хтеле (Milani, 1988, стр. 94, прев. Екер). Забрана се удише као што се удише ваздух, дакле, несвесно. И сама ауторка Милани почела је да пише (али не и да објављује) крајем осамдесетих година, тј. у тренутку у којем су југословенске власти биле најотвореније и најпопустљивије и када је др- 
жава била на ивици распада 9. „Морамо бити хероји да бисмо могли да пружимо отпор средини у којој живимо" (Milani, 1988, стр. 95, прев. Екер), каже главни јунак Утакмище. Он жели и да нам на ироничан начин објасни шта је то „ћутање”:

Професорка соичологије је покушала да нам објасни теорију ћутања: Постоје три претпоставке, рекла је. Једни кажу да су тајни агенти раширили забрану. Други тврде да су добили поштом, као top secret, наредбу о забрани заједно са наређењем да поједу папир чим га прочитају. Али професорка је подржавала треће, оне који су тврдили да уопште није било потребе да се шаље хитно наређење јер смо ми такве овце да смо неком телепатијом наслутили како траже да се понашамо и одмах смо се томе повиновали. (Milani, 1988, стр. 108, прев. Екер, Блатешић)

Данас ова неписана забрана језика у Хрватској више не постоји, а младе генерације плаћају цех ономе што се одиграло после Другог светског рата, још увек осећајући последице тих догађаја. У својим стручним радовима, као на пример у делу Prove di frontiera, prove di vita (Докази са границе, докази живота), Нелида Милани тврди да је нека врста болести погодила италијански компонент у Истри: нека врста афазије која не обухвата само људе него и ствари, па и градове: архитектура и урбанизам су врста израза, као што је то језик, али ћутање (или афазија) може да погоди било коју форму језика (Милани, 2001, стр. 138-143). О значају екстралингвистичких фактора на усвајање језика у билингвалној средини писала је и Трајковић, која је истакла да је билингвалним говорницима отежан процес учења језика, јер се у вишејезичном окружењу налазе у расцепу између стандарда, који чују у школи, из медија, у службеној комуникацији, и дијалекта, са којим се срећу у суседству и на улици. (Трајковић 2013, стр. 126). Суштински појединци усвајају језик(е) онако како им средина то намеће.

Бројни истарски истраживачи разлоге за ову ситуацију проналазе у школском систему и његовој неусклађености са реалним потребама плурилингвалних говорника у мултиетничкој средини. Тако

\footnotetext{
${ }_{9}^{9}$ Ово не значи да су Италијани у Истри једва чекали да се Југославија распадне, напротив! Н. Милани је у разговору са аутором К. Екером изјавила да јој недостаје тај melting-pot, тј. хомогенизација хетерогеног друштва коју је некадашња Југославија гарантовала Истри (Екер, 2011). Још један италијански аутор Лучиферо Мартини је у својим романима приказао мане које су минирале јединственост Југославије, тражећи решење које би спречило распад земље, као уосталом и Клаудио Угуси, који се увек супростављао идеологијама и који је мислио да само нове привредне и друштвене услуге могу да спасу земљу у којој је он живео.
} 
Скоти Јурић указује на важност имплицитних теорија наставника у школама (Scotti Jurić 2011, стр. 43), те у својим истраживањима стиже до закључка да наставници показују недовољну способност у разликовању мултикултуралности од интеркултуралности (Scotti Jurić, Štokovac 2011, стр. 85). Са друге стране, Мочинић указује и на недовољно присуство специфичних културних садржаја у уџбеницима упркос потреби за њиховим укључењем у школске програме и јасне сугестије хрватског Министарства (Мос̌inić 2005).

У једној приповеци насловљеној Impercettibili passaggi (Heприметни пролази), коју је Миланијева написала крајем осамдесетих, млада јунакиња се осећа усамљено и страно у сопственом граду. Нелида Милани не каже који је град у питању, јер то у ствари није битно: градови у Истри су мењали своја лица, док су Италијани задржавали своје осећање отуђености у Пули, Ријеци и Копру:

Понекад ми се чини да је нека врста куге погодила сво људство наше вароши у најтипичнијој вештини: употреби писмене или усмене речи. То је једна од оних напасти које су га много пута погодиле, али се сада показује као губљене спознајне моћи и непосредности. Угашена је свака искра која би севнула из судара са новим речима и новим околностима, са новим догађајима, новим квартовима, а отворене су црне рупе које усисавају памћене. Ово насеље ми нитта не говори, оно нема значене, нема полазних тачака, мутни је универзум, непокретан, у потпуности кодиран на другом језику. Ни симбола, ни трага, ни симптома, ни сигнала, ни позива; свет је чудан и тајанствен; простор лишен познатих елемената који би могли да ме привуку. (Milani, 1991, стр. 92-93, прев. Екер, Блатешић)

Настављамо да пратимо Нелидино излагање:

Деца у школи питају за име ствари како би их на неки начин усвојила. Речи не само да откривају простор, већ морају и да га освоје; свако од нас га осваја сопственим речима, онако како му се свиђа и како му одговара. Банка, туристичка агенциja, пошта, мењачница, читав овај нови део који хаотично меша сељачку и информатичку циивилизацију, понос новопридочлих мени су понекад туђи, или, боље речено, ја се ту осећам као туђинка, у смислу да одбијам да припадам ономе у чему се не препознајем. Треба ми стварност препуна значења, треба ми стварност саздана од именаิ; и најбезначајније ствари именом се претвараjу у најбоље, враћају нам се набрекле од свег људског које смо у юих уложсил; разоткривају своју и нашу душу. (Milani, 1991, стр. 92-93, прев. Екер, Блатешић)

Младе генерације Италијана полако губе „италијанску душу имена". Хрватски и словеначки су језици које млади Италијани највише користе у Истри и које осећају као најугледније у социолошком смислу. Хрватске власти још увек нису потпуно одустале од 
идеје да избришу италијанско присуство у Истри, али је ситуација свакако боља него у прошлости захваљући залагању Истарског демократског сабора, највеће регионалне странке у Хрватској ${ }^{10}$. Треба и да се запитамо да ли је природно да друштвени компоненти полако губе свој језик; то се не дешава само Италијанима у Истри него свима који живе ван своје земље, и то већ након две или три генерације.

Иако Италијани полако губе везу са својим језиком и, каткад, љубав према њему, билингвизам, као и плурилингвизам, још увек су животна реалност младих Италијана у Истри. Песма Лучифера Мартинија El vecio Fiuman (Стари Ријечанин) краћим дијалогом између говорника различитог матерњег језика одлично илуструје језик којим Италијани, а често и Хрвати, још увек причају и који се може чути на улицама Пуле или Ријеке:

\section{Da otanta ani fiuman}

Pietro passa per Cale Canapin (no'l sa gnanca che xe cambià el nome) Aiutandose col baston pian pian el passa tra busi e pietre fate de ricordi El tira el fià e el pensa quando che'l iera mulo e'l tirava sassi ai passeri che'desso no xe più.

"Sior Piero - fa una dona striminzida kako je?" "Ben - el ghe rispondiDobro.

Vame i veci." "I vaša žena?" "Dobro anca ela."

El croato ghe xe dificile e Ruža no la sa el talian. "Ali je bolesna? Nikada ne izlazi."

Piero ghe pensa su. "No-el rispondino laxe

bolesna, pigrizia, solo pigrizia."

"Ah - fa la Ruža - Bolesna od

pigrizie."

e tuti e due soridi. Come xe bel capirse.
Већ осамдесет и кусур година Пјетро пролази сокаком Канапина (и не зна да је променио име) Помажући се штапом, миц по миц, пролази кроз рупе и камење од сећања, уздише и мисли на детињство, када је бацао камење на врапце којих више нема.

„Гос'н Пјеро - каже једна слабуњава жена -

како је?” „Добро - одговара он Добро.

Како мора, старачки.” „А ваша жена?” „Добро је и она.”

Хрватски је тежак, а Ружа не зна италијански. ,Је л' можда болесна? Никада не излази?"

Пјеро се замисли. ,Не - одговара није болесна; то је лењост, само лењост."

„Ах - каже Ружа - болесна од лењости"

и обоје се насмеју. Како је лепо разумети се. (Martini, 1982, стр. 49, прев. Екер, Блатешић)

\footnotetext{
${ }^{10}$ Ова парламентарна странка основана је у Пули 1990. године, а међу њених 6000 чланова налазе се како Хрвати тако и Италијани. Према основној програмској декларацији, ИДС се залаже за већу демократију у Хрватској, аутономију Истре и стварање трансграничне еурорегије Истре (више о томе на веб-страници: http://www.ids-ddi.com/).
} 
Приликом постављања питања и давања одговара у овој песми запажамо неколико примера интерференције у којима говорници користе један језик као доминантан, док се другим служе у оноликој мери колико им је познат, без одређеног правила. Тако Ружа, која зна да је Пјеро Италијан, у обраћању користи истровенетске речи sior Piero, да би у даљој комуникацији наставила на хрватском „kako je?”. На сличан начин јој одговара Пјеро, служећи се првобитно истровенетском речју ben, коју одмах потом преводи на хрватски „dobro”. Овај хрватски прилог користи још једном, одговарајући на друго Ружино питање постављено на хрватском „I vaša žena?”. Ружа се у наставку конверзације и даље служи хрватским, али њен саговорник успева да издвоји кључну хрватску реч „,bolesna”, коју потом користи у свом одговору на истровенетском „No - el rispondi - no la хе bolesna, pigrizia, solo pigrizia”. На крају овог разговора Ружа уноси у одговор кључну италијанску реч pigrizia, коју деклинира као да припада хрватским именицама женског рода које се у номинативу завршавају на $-a$; „Болесна од pigrizie”. У закључку саговорници донекле мењају првобитно значење, али на веома симпатичан начин, чиме не ремете основни комуникацијски код. Тако се значења „бити болестан” и „бити лењ” у овом примеру језичке интерференције изједначавају, с тим да обична лењост постаје „болест од лењости”. Упркос томе што Ружа не зна италијански, а Пјеро не уме да прича хрватски, они се добро разумеју, јер разазнају кључне речи дискурса. Последњи стих песме ставља нам до знања да они то виде као предност: Coте xe bel capirse (Како је лепо разумети се).

Ова песма, као и претходни примери, осликава типичан, свакодневни истарски феномен, билингвалну комуникацију, која због плурикултуралности уступа место плурилингвалној способности, тј. „познавању више језика и култура којима се корисници служе у комуникацији и друштвеној интеракцији на различитим нивоима" (Заједнички европски оквир 2003, стр. 183). Књижевност нам у овом случају помаже да разумемо језик који се користи у Истри и Ријеци, a још и данас је могуће чути разговоре попут овог из Мартинијеве песме, и то не само на улици и на пијаци. Водитељи емисија на локалним радио-станицама, као на пример на Радију Пули ${ }^{11}$, намерно мешају језике како би истакли вредност интеркултуралности која влада у целој Истри.

Ова нова варијанта језика којим се служе Италијани у Истри подсећа на процес креолизације, када услед усвајања периферних варијетета језика колонизатора и губљења контакта са централним моделом ти варијетети постају аутономни (Дробњак 2007: 314). Како

${ }^{11}$ Овај радио могуће је слушати и преко интернета: http://radio.hrt.hr/radio-pula. 
Кауфман и Томасон истичу, све контактне ситуације своде се на чување језика или његову замену доминантнијим (Русаков 2007: 79). У првом случају долази до интерференције најпре на лексичком нивоу, док су при смени језика уочљиви фонетски, граматички и најчешће синтаксички утицаји другог језика (Русаков 2007: 80), као што смо имали прилике да видимо у претходно описаном примеру.

\section{ЗАКЉУЧАК}

Дугачак је и тежак пут од мртвог слова на папиру, макар он потицао од високе политичке инстанце као што је Европска унија, до потпуно слободног прожимања различитих језика и дијалеката. Тако у политици Савета Европе остаје нерешено питање спровођења те важне акције очувања разних европских језика, поготово у земљама Европске уније које су све чешће крајња дестинација бројних имиграната. Обично је тај процес језичке асимилације, са једне стране, и очувања сопственог језика са друге, препуштен потпуно природном процесу интеграције пристиглог становништва и њиховој самосталној иницијативи у организовању начина очувања матерњег језика. Иако је потреба за оваквим видом борбе и неговања свог језика и културе препозната, још увек недостају предлози конкретних корака и мера које треба предузети на том путу. Регија у Истри представља прави пример једне изузетно сложене социолингвистичке ситуације у којој велику улогу има историјски фактор.

Анализа истовремене употребе више језичких кодова показала нам је да се таква врста комуникације у неформалном контексту обавља са лакоћом у регији у којој се сусрећу говорници више језика, док на територији где доминирају једнојезични говорници и где је контекст изразито формалан представља извор неспоразума. На то делимично утичу језичке интерференције плурилингвалних говорника које делују збуњујуће на једнојезичне саговорнике, али и низак ниво толерисања „другачијег” говора. Пошто је свака плурилингвална средина и плурикултурна, за слободну комуникацију на више језика неопходно је развити висок степен свесне толерантности и отворености према постојећим културама дате средине, што се може постићи само превазилажењем социолошких и политичких несугласица насталих током историје контаката тих народа. 


\section{ЛИТЕРАТУРА}

Baker, C. (1996). Foundations of Bilingual Education and Bilingualism. Clevedon: Multilingual Matters.

Bertini Malgarini, P. (1994). L'italiano fuori d'Italia. In: Storia della lingua italiana, a cura di L. Serianni \& P. Trifone. Torino: Einaudi, Vol. 3, 883-992.

Bialystock, E. (2001). Bilingualism in Development: Language, Literacy and Cognition. New York-Cambridge UP.

Bogojević, D. (ured.) (2003). Zajednički evropski okvir za žive jezike: učenje, nastava, ocjenjivanje [Common European Framework of Reference for Languages: Learning, Teaching, Assessment]. Podgorica: Ministarstvo prosvjete i nauke.

Бошњаковић, Ж. Радовановић, Д. (2009). Теренски записи из Малог Гаја (Румунија) [A Field recording of the vernacular from Mali Gaj in Romania]. У: Прилози проучавағу језика [Contributions to the Language Studies], 40, 161-178.

Бошњаковић, Ж, Радан, М. Н. (2010). Досадашња истраживања о утицају румунског језика на лексику српских говора румунског дела Баната [All researches conducted so far the Influence of the Romanian Language on the Lexicon of the Serbian Vernaculars in the Romanian Banat]. У: Јужнословенски филолог [South Slavic Philologist] LXVI, 135-161.

British Council (2012). Language Rich Europe. Tendenze nelle politiche e nelle pratiche per il multilinguismo in Europa. Retrieved $1^{\text {st }}$ April 2016 from http: //www.languagerich.eu/fileadmin/content/pdf/LRE_Italian_Language_Rich _Europe_-_Tendenze_nelle_politiche_e_nelle_pratiche_per_il_multilinguisno_in_ Europa.pdf

Daloiso, M. (2009). La lingua straniera nella scuola dell'infanzia. Torino: Utet Università.

Drobnjak, D. (2007). La creolisation et les langues creoles. У: Годишъак Филозофског факултета у Новом Саду [Annual Review of the Faculty of Philosophy University of Novi Sad] XXXII, 303-314.

Eccher, Ch. (2012). La letteratura degli italiani dell'Istria e di Fiume dal 1945 a oggi. Fiume/Rijeka: Edit.

Eкер, К. (2012). Нелида Милани и трагедија језика [Nelida Milani and the Tragedy of Language]. У: Пољ $а$, год. 57, бр. 476, 142-149.

Fabbro, F. (1996). Il cervello bilingue. Neurolinguistica e poliglossia. Roma: Astrolabio.

Forza, S. (2010). Italiani sbagliati. La Voce del Popolo, inserto "in più cultura", anno V, N. 46, 1 .

Hnízdo, B. (2008). The types of the European Plurilingualism: Gateways to Creation of Transnational Identities. In: Annual of Language \& Politics and Politics of Identity, 7-15.

Kendall, K. A. (2006). Child language acquisition. In: An Introduction to Language and Linguistics. Cambridge University Press, 205-224.

Lalli Paćelat I, Stokovac, T. (2011). La competenza interculturale degli studenti di lingua e cultura italiana: il ruolo del contesto di appartenenza. In: (Scotti Jurić, R, Štokovac, T, a cura di) Studi interculturali. Interferenze linguistiche, didattiche e culturali nel territorio istroquarnerino. Pola: Università "Juraj Dobrila", 81-109.

Luise, M. C. (2013). Plurilinguismo e multilinguismo in Europa per una Educazione plurilingue e interculturale. In: Lingue e letterature d'Oriente (2), 525-535.

Martini, L. (1982). Antologia delle opere premiate "Istria nobilissima". U.I.I.F. U.P.T, Fiume - Trieste.

Milani, N. (1988). La partita. In: Antologia delle opere premiate "Istria nobilissima". Fiume - Trieste: U.I.I.F. - U.P.T.

Milani, N. (1991).Una valigia di cartone. Palermo: Sellerio. 
Milani, N. (1996). L'ovo slosso - Trulo jaje. Fiume/Rijeka: Edit.

Milani, N. (2001). Prove di frontiera - Prove di vita. In: Tomizza i mi. Susreti uz granicu/ Tomizza e noi. Incontri di frontiera. Zbornik radova međunarodnog skupa Forum Tomizza. Umag-Koper: Pučko Otvoreno Sveučilište, 138-143.

Milani, N. (2003). L'italiano fra i giovani dell'Istro-quarnerino. Pula - Rijeka: Pietas Iulia - Edit

Močinić, S.N. (2005).Contenuti culturali specifici nei libri di testo per la minoranza italiana in Croazia. Percorsi didattici 4, Edit - Unione italiana, Fiume, 37-76.

Peal, E., Lambert, W. E. (1962). The relation of bilingualism to intelligence. In: Psychological Monographs: General and Applied, 76 (27), 1-23.

Rumici, G. (2001). Fratelli d'Istria. Milano: Mursia.

Сапир, Е. (1984). Огледи из културне антропологије [Selected writings of Edward Sapir in language, culture and personality]. Београд: Просвета.

Saussure, F. De (1970). Corso di linguistica generale. Roma - Bari: Laterza.

Scotti, G. (2002). Goli Otok: ritorno all'isola calva. Trieste: Lint.

Scotti Jurić, R, Štokovac, T. (2009). La scuola su misura delle classi multietniche e plurilingui: teorie linguistiche implicite. In: (Kadum, V. Ed.)

Škola po mjeri [Custom Made School]. Sveučilište Jurja Dobrile u Puli.

Scotti Jurić, R, Štokovac, T. (2011). Studi interculturali. Interferenze linguistiche, didattiche e culturali nel territorio istroquarnerino. Pola: Università "Juraj Dobrila".

Станковић, С. (2004). Македонци и македонски језик у Републици Србији — Pro et contra [Macedonians and Macedonian language in the Republic of Serbia - Pro et contra]. У: Зборник радова са међународног научног скупа Скривене мањине на Балкану, Београд, 25-26. IX 2003 [International Conference Proceedings Hidden minorities in the Balkans, Belgrade, 25-26. IX 2003], Српска академија наука и уметности, Балканолошки институт, Посебна издања [Serbian Academy of Sciences and Arts, Institute for Balkan Studies, Special editions], 82, 41-49.

Трајковић, Т. (2013). Српски говор Алабанаца у Прешеву. [The Serbian speech by Albanians in Presevo]. У: Српски језик, књижевност, уметност. Зборник радова са 7. Међународног научног скупа на Филололошко-уметничком факултету у Крагујевцу [Book of conference proceedings, Seventh International Conference: Serbian Language, Literature and Arts, Faculty of Philology and Arts, University of Kragujevac],125-134.

Ugussi, C. (2009). La città divisa. Rijeka/Fiume: Edit.

Ugussi, C. (2002). Alcuni aspetti della cultura degli italiani in Croazia. Posizione delle minoranza italiana in Croazia. Helsinki - Zagreb: Helsinški komitet za ljudska prava.

Русаков, А. (2007). Славяанские яезыки на Балканах: Аспекты контактного взамоидействия. Ареальное и генетическое в структуре славяенских языков. Материалы круглого стола. Российская академия наук. Институт славяноведения. Москва, 77-89.

Zvekić-Dušanović, D. (1999). O neadekvatnoj upotrebi morfeme se u produkciji mađarsko-srpskih bilingvalnih govornika [On the inadequate use of the Serbian morpheme se as produced by Hungarian-Serbian bilingual speakers]. Zbornik Matice srpske za filologiju i lingvistiku [Matica Srpska Journal of Philology and Linguistics] XLII, 219-224. 


\title{
SOCIOLINGUISTIC VIEW ON CONTEMPORARY LANGUAGE OF ITALIANS IN ISTRIA AND RIJEKA
}

\author{
Aleksandra Blatešić, Christian Eccher \\ University of Novi Sad, Faculty of Philosophy, Novi Sad, Serbia
}

\begin{abstract}
Summary
In this paper, we show the basic features of the language spoken by the Italians in Istria, which is not always the standard Italian, but also Croatian and Istrian - Venetian dialect. Today's speakers are prone to mixing different languages and dialects in one discourse, while the kind of language which will be used, and the context of use depend on numerous sociological factors. Family environment requires the use of the Istrian Venetian dialect, meanwhile for the formal interview it is more suitable to use standard Italian or Croatian. To understand the basic motive of the Italians in Istria and Rijeka when choosing a particular language in a particular situation, we have to look back at their sociopolitical position in the period after the Second World War, in which the Italians came up with the complex minority.

As will later be clearly shown, a moment of secession from the home country of Istria had very dramatic consequences for its inhabitants, who are suddenly a "minority" left to the will and decisions of the "majority", with which they did not even speak the same language. In a situation of complete hopelessness, feelings of alienation and loneliness many Italians left Istria forever, while those remaining turned to their inner world, giving priority to the written, rather than spoken language. In this context, literature has become a place of meeting with compatriots and the only place of preserving their own identity, national and linguistic affiliation. It has become a common thing for Istrian Italians who felt discomfort in numerous social relationships. The literary novels of the Italian university professor sociopsycho - linguistics Nelida Milani content many diverse examples of the description of the social situation and psychological condition of Istrian Italians in numerous sociological roles and contexts. The author, in fact, managed to very accurately bring to the surface the existential and psychological problems of Italians in a rather complex political situation, which is clearly reflected in the language that they are speaking. The population of the region has come a long way from the "silence allowed" to free speech, which abounds in a mixture of languages and dialects, characteristic for this plurilinguistic and pluricultural environment. Today's Istrian Italians, however, faced with completely different difficulties, and that is dealing with the speakers of their native language in their home country. Speech of young Italians in Istria is not fully understood by their peers in Italy, and in social interaction it seems marked by the social group. Take, for example, the language spoken by the Italians in Istria in different social contexts and roles to point out real problems the speakers are facing in a plurilinguistic and pluricultural environment, which should be taken into account in the creation and implementation of language policy in every country of Europe.
\end{abstract}

